\title{
Is Employee Performance Affected by Organizational Cuoture, Work Motivation and Organizational Citizenship Behavior (OCB)?: An Empirical Investigation
}

\author{
Muzakki $^{1}$, Anis Eliyana ${ }^{2}$, Ridan Muhtadi ${ }^{3}$ \\ Airlangga University ${ }^{1}$ Airlangga University ${ }^{2}$, STAI Miftahul Ulum, Pamekasan, Indonesia ${ }^{3}$ \\ muzakki-2018@feb.unair.ac.id
}

\begin{abstract}
The purpose of this research is to examine and analyze the influence of organizational culture, work motivation and organizational citizenship behavior (OCB) to employee performance. This research is conducted in Pamekasan Regency Government. The samples of this research are 116 respondents. The sample technique which used in this research is proportional stratified random sampling. This study employs questionnaire by a large number of answers based on a 5-point likert scale to collect the needed data and information. The result of this research reveals that the work motivation and organizational citizenship behavior (OCB) influence to employee performance significantly. Nevertheless, organizational culture has not significant effect on employee performance at Pamekasan Regency Government.
\end{abstract}

Keywords: organizational culture, work motivation, organizational citizenship behavior (OCB), employee performance.

\section{INTRODUCTION}

Every organization, both private organizations and government organizations in general, considers that employee is one of the important factors to support the success of all organizational activities. In this case, the organization requires employee as the driver of all operational activities [1]. Organizations to achieve their goals must have competent employees who can be used at the right time and the right place [2]. On the other hand, organizations need to improve employee performance which is demonstrated through the work achieved by employees from work related to organizational goals, efficiency and effectiveness [3].

Employee performance is shown through the work achieved by employees during a certain period of time in a particular field of work [4]. Employee performance can also affect organizational performance [5], in order to create a performance that is in line with what is expected by the organization, the leader must be able to create a work environment that is conducive and sensitive to employee conditions, while to have a good performance the employee must have expertise and skills that are appropriate for the work they have.

According to the report was said by The Minister of Administrative and Bureaucratic Reform (Kemenpan-RB) in 2018 related to the employee performance of government organization, there are around 1.35 million employee (30 percent) which has poor performance values, in carrying their daily duties, they were not follow the rules and tend to not want to know (Koran Sindo, 2018) [6]. This has provided evidence that the issue of employee performance in government organizations has become the main spotlight for the government which it is described as having a low level of professionalism, capacity of the service did not optimal, lacking integrity as employee of government so that they did not have emotional ties with their agencies and duties. The performance problem which has discussed, according to [7] were caused by the application of a less optimal organizational culture. In their empirical study proved that organizational culture has an effect on increasing employee performance.

organizational culture has defined as a shared value system that determines how employees carry out activities to achieve the goals of an organization [4]. The same thing was also stated by [8], which describes as shared sense, and 
organizational culture must be taught to members including new members to have the same perceptions held by members of the organization. Long-term consistency is needed to implement values and actions that are considered important for the organization. Studies in the 1980s and thereafter, have proven that organizational culture has a significant influence on performance, job satisfaction, morale, loyalty and employee involvement, turnover, commitment, employee attitudes and motivation, and efforts to attract and retain talented employees (e.g; [9]; [10]; [11]; [12]; [13]). Until now, empirical studies related to the influence of organizational culture on employee performance still exist to be studied by many experts (e.g; [14]; [15]; [16]).

Another factor that influence employee performance is work motivation [17] and [18]. According to Robbins [4] to optimize employee performance is needed the motivation, motivation is defined as a process that explains the intensity, direction, and perseverance of an individual in achieving a goal. From that definition, it can be seen that motivation is an important part of the individual basis in doing something or achieving a certain goal. [19] documented that someone who has high achievement motivation depends on the results of the work received to meet needs and satisfaction, namely material and nonmaterial satisfaction. it means that if material and non-material received are more satisfying, then the morale of employees' performance will increase, and the higher standard of desired needs, the more someone who will work actively. [20] found that motivation has an important effect on employee performance. The results of the same study were also found by [21], providing evidence that work motivation has a significant effect on employee performance.

In other side, to improve employee performance in the organization. Employees are expected to have the ability to work in teams including interpersonal skills. This skill can be demonstrated by employees who care for other employees who try to display the best outside the organization's duties. [22] explained that one of the main reasons why OCB has attracted the attention of academics and practitioners is because of the proven significance of organizational effectiveness. [23] explained that OCB affects organizational performance through increasing the efficiency of co-workers and managers; increasing resources for more productive activities and goals effectively; making organizations more responsive to change in the environment; assisting team coordination for productive work; strengthening the ability to attract and retain talented employees and improve organizational stability. According to [24] OCB is an extra-role behavior that is owned by an employee to improve organizational effectiveness and efficiency, this behavior is usually indicated by helping employees even though they do not need, helping colleagues who have not worked, and helping managers to promote organizational effectiveness. In this case, [25] found that OCB affects employee performance positively and can improve the quality of ethos in public service in UK. Similar results were also obtained by [26]; [27] which the OCB has a positive and significant impact on employee performance.

\section{LITERATURE REVIEW AND HYPOTHESES DEVELOPMENT}

\subsection{Organizational Culture}

Culture is a set of shared meanings that allow group members to interpret and act on their environment [28]. According to [29] organizational culture is a habit that has lasted a long time, used and applied in carrying out organizational activities as one of the drivers to improve the quality of work of employees or superiors. Generally, organizational culture is identified through stories, special languages, artifacts and norms that arise from individual and organizational behavior ([30]; [31]). Organizational culture has several functions within the organization, such as; culture has a role in setting boundaries, meaning culture creates clear differences between one organization and another; culture makes it easier to commit to areas greater than one's personal interests; culture brings a sense of identity to members of the organization; culture serves as a mechanism for making meaning and control that guides and shapes employee attitudes and behavior; and culture can improve system stability [32]. Organizational culture can bring the organization better, and has a significant impact on employee performance ([14]; [15]; [16]).

\subsection{Work Motivation}

Work motivation is defined as the desire in employees who provide strength to meet their needs and play a strong role in directing behavior, or cause employees to take action in achieving organizational goals [32]. According to [34] work motivation is a stimulant of desire and driving force of willingness to achieve the desired goals. The well-known and often heard motivational theory is the hierarchy of needs triggered by Abraham Maslow. Maslow in [35], said that each individual has five levels of needs, namely; (1) psychological needs which include: hunger, thirst, sex, protection (clothing and housing) and other physical needs; (2) security which include: safety and protection against physical and emotional loss (4) Rewards which include: self-esteem, autonomy, and achievement as well as external 
respect factors such as status, recognition and attention; (5) Self-actualization which is an impulse to become someone or something in accordance with his ambition which includes growth, achievement of potential and self-fulfillment. Empirical studies have proven that work motivation has a positive and significant impact on employee performance ([17]; [18]; [20]; [21]).

\subsection{Organizational Citizenship Behavior (OCB)}

In the late 1970s the term OCB was made by [36] to describe innovative and cooperative behavior through the relationship between job satisfaction and performance. [36] argued OCB as voluntary behavior, choices and individual initiatives that are not directly related to the organization's formal reward system, but as a whole can improve the organizational effectiveness. Another opinion, OCB is referred to as individual behavior that is influenced by interpersonal trust and facilitates the operation of the organization by performing tasks outside the organizational prerequisites that are not directly recognized by the formal reward system [37]. Some elements of OCB behavior such as; helping others, adhere to the rules and procedures in the workplace, and volunteering for extra duties. These behaviors are constructive, meaningful and positive behavior [38]. According to [39], OCB contributes to organizations as well as increasing colleague productivity, increasing manager productivity, saving resources owned by management and the organization as a whole, helping to maintain group functions, being very effective in coordinating work group activities, increasing the organization's ability to attract and retain the best employees, improve organizational stability, enhance the organization's ability to adapt to environmental changes. in several studies were found that OCB has a significant impact on employee performance [27] \&[26]. it's Mean that employees who have OCB can improve employee performance both for the organization and for themselves.

\subsection{Performance}

Performance is defined as a measure of the results of a good quality and quantity in a certain time period that is influenced by many factors and carried out with the responsibility given to achieve organizational goals by employees [40]. It represents the levels of achievement of each job [41]. According to [42] employees' performance is the work of an employee during a certain period compared to various possibilities, i.g; standards, targets or criteria that are determined and mutually agreed upon. Employee performance is a factor that can significantly influence organizational profitability [43]. On the other hand, there are two factors that influence employee performance, namely internal and external factors [44].

Based on the established evidences, the researcher proposes three hypotheses on this research.

H1: Allegedly organizational culture has a significant effect on employee performance.

H2: Allegedly work motivation has a significant effect on employee performance.

H3: Allegedly OCB has a significant effect on employee performance.

\section{METHOD}

The research design used in this study is quantitative research. Variables in this study are organizational culture, work motivation, and OCB as exogenous variables, and employee performance as endogenous variables. The population in this study are all employees who are in Pamekasan Regency Government for III A-D Group. The total population of 3.580 employees, and the sample used for this study are 116 samples after being calculated using the Slovin formula. The sampling technique is used proportional stratified random sampling. A structured questionnaire is used to collect data that is relevant to this study.

The Measurment of organizational culture, we used 9 items based on organizational culture scale [45]. To assess work motivation in this study 5 items were used [34]. While OCB, we used 5 questionnaire items from Organ et. al., in [46]. Furthermore, to assess employee performance, we used 4 employee performance items based on [47]. All measurement of four variables rated on 5-point Likert type scale ranging from 1 (strongly dissagre) to 5 (strongly agree). All items have a validity score of up to 0.6, and a reliability score above the significance level of 0.05 [48], and Hypotheses tests are conducted by multiple linear regression, with the following equation:

$$
\mathrm{Y}=\mathrm{a}+\mathrm{b}_{1} \mathrm{X}_{1}+\mathrm{b}_{2} \mathrm{X}_{2}+\mathrm{b}_{3} \mathrm{X}_{3}+\mathrm{e}
$$

Explanation:

Y : employee performance 
a : value of $\mathrm{Y}$ if $\mathrm{X} 1, \mathrm{X} 2=0$

$b_{1}, b_{2}, b_{3}$ : coefficients of regression

$\mathrm{X}_{1} \quad$ : organizational culture

$\mathrm{X}_{2} \quad$ : work motivation

$\mathrm{X}_{3} \quad$ : OCB

e $\quad$ : residual value

\section{RESULTS}

Data was analyzed by using multiple regressions to test the relationship between organizational culture, work motivation, OCB and employee performance. Thus, by applying a multiple regression technique we can also determine specific independent variables that have a major influence on a dependent variable [49]. The results of this study can be seen in the table below:

Table 1. Result of test for coefficient of determination

Model Summary ${ }^{b}$

\begin{tabular}{|c|c|c|c|c|}
\hline Model & R & R Square & Adjusted R Square & Std. Error of the Estimate \\
\hline 1 & $.749^{\mathrm{a}}$ & .560 & .549 & 1.71874 \\
\hline
\end{tabular}

a. Predictors: (Constant), OCB, Work Motivation, Organizational Culture

b. Dependent Variable: Employee Performance

Table 2. Summary of Multiple Regression for Employee Performance

\begin{tabular}{lcccc}
\hline Independent Variables & Expected sign & $\boldsymbol{\beta}$ & t-statistics & P-value \\
\hline X1 Organizational Culture & + & 0.039 & 1.665 & $0.507^{*}$ \\
X2 Work Motivation & + & 0.279 & 3.415 & $0.001^{*}$ \\
X3 OCB & + & 0.507 & 7.424 & $0.000^{*}$ \\
\hline Adjusted R ${ }^{2}$ & \multicolumn{4}{c}{0.549} \\
\hline N & \multicolumn{5}{c}{116} \\
Notes: ${ }^{*}$ Significance at 0.05, respectively; Dependent variables = Organizational Culture; Work Motivation; OCB.
\end{tabular}

According to the table 1, the Adjusted R Square number is 0.549 or $54.9 \%$. This showed that the percentage of the influence of the organizational culture $\left(\mathrm{X}_{1}\right)$, work motivation $\left(\mathrm{X}_{2}\right)$, OCB $\left(\mathrm{X}_{3}\right)$ on the dependent variable $(\mathrm{Y}=$ employee performance) of $54.9 \%$. So that, it can be said that the variation of the independent variable used in the model is able to explain $54.9 \%$. While the remaining $45.1 \%$ is influenced or explained by other variables.

The table above showed that the t test of the influence of organizational culture on employee performance produces t-statistics $=1.665, \beta=0.039, p$-value $=0.507, p>0.05$, it is concluded that organizational culture has no significant effect on employee performance. These results contradict the results obtained by previous researchers in this study ([14]; [15]; [16]). Work motivation produces t-statistics $=3.415, \beta=0.279$, $\mathrm{p}$-value $=0.001$, $\mathrm{p}<0.05$, so it is concluded that work motivation has a significant effect on employee performance. These results support the findings of previous researchers ([17]; [18]; [20]; [21]). While OCB produces t-statistics $=7.424, \beta=0.507$, $p$-value $=0,000$, $\mathrm{p}<0.05$, so it is concluded that OCB has a significant effect on employee performance. This results supported the findings of previous researchers who stated that employees who have good OCB can improve performance for both the organization and for themselves ([27]\& [26]).

\section{DISCUSSION}

This study showed that organizational culture has no significant effect on employee performance. As seen in table 2 , this is because employees assumed that organizational culture indeed should exist, and organizational culture is commonplace and normal so that organizational culture has no significant effect on employee performance, and this results supported the research of [50] and [51]. While, work motivation and OCB play an important role in influencing employee performance. As can be seen in table 2, work motivation and OCB show a significant influence on employee performance. This finding demostrates important aspect of employee performance in the Pamekasan Regency 
Government. The three predictor variables proposed in this study, the variable that has the most dominant influence is OCB, which is $50.7 \%$ can improve employee performance. Thus, for the government as the holder of power and policy maker to make meaningful decisions or formulate policies in the Pamekasan Regency Government. The components that have both work motivation and OCB proposed as predictors in this study must be given priority in policy implementation. This is because they play an important role in influencing the performance of Pamekasan Regency Government employees. based on the analysis and outcome of this study, the models that can be developed are as follows.

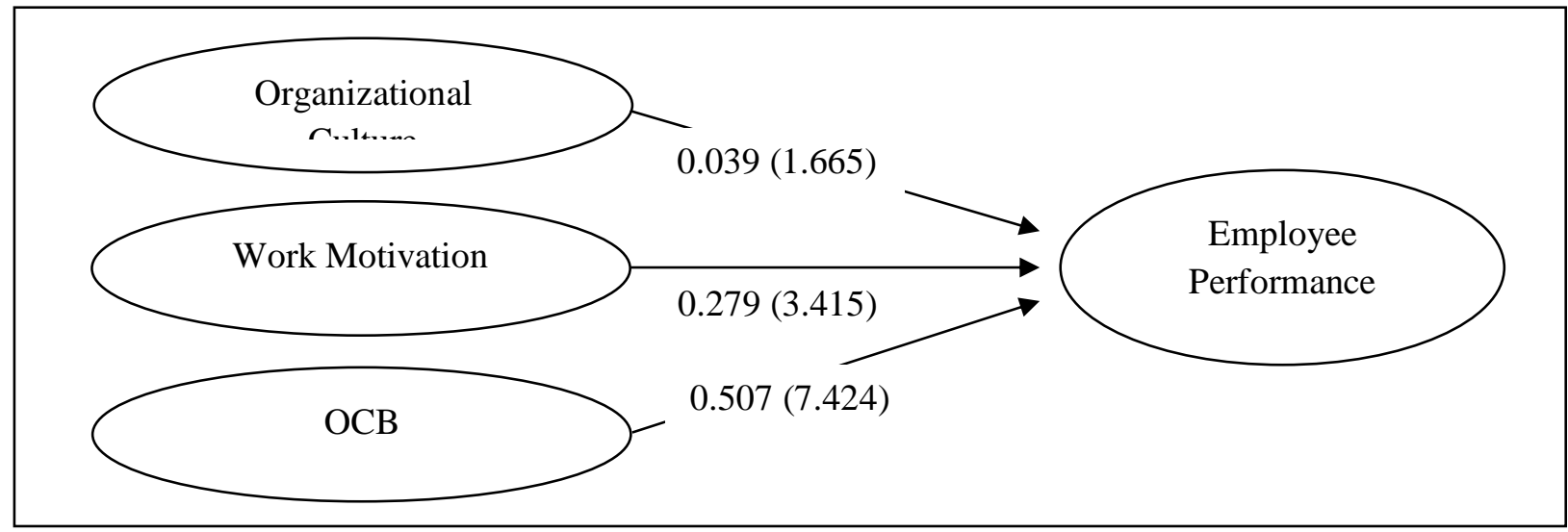

Fig. 1. Model for Employee Performance

\section{CONCLUSION}

Based on the statistical test has been done, it can be concluded as follows:

1. Organizational culture has no significant effect on employee performance at Pamekasan Regency Government.

2. Work motivation has significant effect on employee performance at Pamekasan Regency Government.

3. OCB has significant effect on employee performance at Pamekasan Regency Government.

\section{Acknowledgments}

The author is very grateful to the Pamekasan Government for helping in the process of completing this research, and for the reviews that have provided many comments for improvement of the research.

\section{REFERENCES}

[1] Abrivianto P., Okto, B., Swasto, U., \& Hamidah, N.: Pengaruh motivasi kerja dan komitmen organisasional terhadap kinerja karyawan (Studi pada karyawan bagian HRD PT. Arthawena Sakti Gemilang Malang). Jurnal Administrasi Bisnis (JAB), Vol 7(2) (2014).

[2]. Marwansyah.: Manajemen Sumber Daya Manusia. $2^{\text {nd }}$ edition. Alfa Beta, cv. Bandung (2014).

[3] Chao, M. C., Jou, R. C., Liao, C. C, and Kuo, C. W.: Workplace stress, job satisfaction, job performance, and turnover intention of health care workers in rural taiwan. Asia Pacific Journal of Public Health 20(10), pp. $1-10$ (2015).

[4] Robbins, P. S.: Organizational Behaviour, $5^{\text {th }}$ Edition, Perilaku Organisasi, Translated by Drs. Benyamin Molan. Salemba Empat. Jakarta (2008).

[5] Koesmono, H. T.: Pengaruh budaya organisasi terhadap motivasi dan kepuasan kerja serta kinerja karyawan pada Sub Sektor Industri Pengolahan Kayu Skala Menengah di Jawa Timur. Jurnal Manajemen \& Kewirausahaan, Vol 7(2), pp. 171-188 (2005).

[6] cari berita yang koran sindo terkait dengan kinerja pegawai pemerintah 
[7] Widarsih, R. W., Madhakomala., \& Supriyati, Y.: The effect of organizational culture, personality, and job satisfaction toward employees performance in directorate general of industrial resilience and international access development. International Journal of Scientific Research and Management (IJSRM) Vol 06, issues 03 pp. 183 190 (2018).

[8]Glaser, B \& Strauss, A. L.: Educational Research: Competencies For Analysis and Application. Merril Publication Company, Colombus (1987).

[9]Fisher, C.: Like it or not . . culture matters. Employment Relations Today, Vol 27(2), pp. 43-52 (2000).

[10]Rollins, T., \& Roberts, D.: Work culture, organizational performance, and business success.: Quorum Books. Westport, CT (1998).

[11]Weiner, Y.: Forms of value systems: A focus on organiza-tional effectiveness and cultural change and maintenance. Academy of Management Review, Vol. 13(4), pp. 534-545 (1988).

[12]Denison, D. R.: Corporate culture and organizational effectiveness. Wiley, New York (1990).

[13]Marcoulides, G. A., \& Heck, R. H.: Organizational culture and performance: Proposing and testing a model. Organization Science, Vol. 4 (2), pp. 209-225 (1993).

[14]Nusari, M., Al Falasi, M., Alrajawy, I., Khalifa, G. S., \& Isaac, O.: The Impact of Project Management Assets and Organizational Culture on Employee Performance. International Journal of Management and Human Science (IJMHS). Vol 2, Issue 3, pp. 15-26 (2018).

[15]Paais, M.: Effect of work stress, organization culture and job satisfaction toward employee performance in bank maluku. Academy of Strategic Management Journal. Vol 17, Issue 5, pp. 1-12 (2018).

[16]Mohammed \& Idris, J.: An assessment of the impact of organizational culture on employee performance. nternational Journal of Development and Management Review (INJODEMAR). Vol.12 No. 1, pp. 178-183 (2017).

[17]Harlie, M.: Pengaruh disiplin kerja, motivasi dan pengembangan karier terhadap kinerja pegawai negeri sipil pada Pemerintah Kabupaten Tabalong di Tanjung Kalimantan Selatan. Jurnal Manajemen dan Akuntansi, Vol. 11(2), pp. 117-124 (2010).

[18]Baloch, S., Mohsin, S., Mohsin, A. B., Ahsan S., Memon, F, H.: The influence of motivation on performance of public sector employees. $6^{\text {th }}$ Annual International Conference On Qualitative and Quantitative Economics Reseach (QQE 2016).

[19]Mariyanti, S., \& Renny, M.: Peranan motivasi berprestasi terhadap prestasi kerja pada agen yang bekerja di Kantor Operasional Pondok Gede dan Kalimalang AJB Bumiputera 1912 Cabang Jakarta Timur. Jurnal Psikologi, Vol. 5 (1), pp. 1-29 (2007).

[20]Nabi, N., Islam, M., Dip, T. M., Al Hossain, M. A.: The impact of motivation on employee performances: a case study of karmasangsthan bank limited, bangladesh. International Journal of Business and Management Review. Vol.5, No.4, pp.57-78 (2017).

[21]Hidayah, T \& Tobing, D. S. K.: The influence of job satisfaction, motivation, and organizational commitment to employee performance. International Journal of Scientific \& Technology Research. Vol 7, Issue 7, pp. 12-127 (2018).

[22]Alkahtani A.: Organizational citizenship behavior (OCB) and rewards. International Business Research, (2015). Vol 8(4), pp. 210-222 (2015).

[23]Podsakoff, P. M., MacKenzie, S. B., Paine, J. B., \& Bachrach, D. G.: Organizational citizenship behaviors: A critical review of the theoretical and empirical literature and suggestions for future research. Journal of Management, Vol. 26(3), pp. 513-563 (2000).

[24]Ryan, J. J.: Work Values and Organizational Citizenship Behaviors: Values That Work for Employees and Organizations. Journal of Business and Psychology, 17(1) (2002).

[25]Rayner, J., Alan, L., \& Helen, M. W.: Organizational Citizenship Behavior and the Public Service Ethos: Whither the Organization?. Springer Science, Business Media B.V. Vol 106 pp. 117-130 (2011).

[26]Al-Mahasneh, M. A.: The impact of organizational citizenship behavior on job performance at greater amman municipality. European Journal of Business and Management, Vol. 7(36), pp. 108-118 (2015).

[27]Ticoalu, L, K..: Organizational Citizenship Behavior (OCB) and Organizational Commitment Influence on Employee Performance. Journal of Economic Research, Management, Business and Accounting. Vol 1, 4 pp. 709 - 820 (2013).

[28]Schein, E. H.: Coming to a new awareness of organizational culture. Sloan Manag, Vol. 25(2), pp. 3-16 (1984).

[29]Fahmi, I.: Perilaku organisasi teori, aplikasi, dan kasus. Alfa Beta. Bandung (2014). 
[30]Deal, T. E., Kennedy, A. A.: Corporate Cultures: The Rites and Rituals of Corporate Life. Reading, MA. AddisonWesley (1982).

[31]Cameron, K. S., \& Freeman, S. J.: Cultural congruence, strength and type: relationships to effectiveness. Res. Organ. Change Dev. 5, pp. 23-58 (1991).

[32]Robbins, S. P. Organizational Behavior, $10^{\text {th }}$ Edition, PT Index. Jakarta (2006).

[33]Mathis, R. L., Jackson, J. H. Human Resoure Management: Manajemen Sumber Daya Manusia. Translated by Dian Angelia. Salemba Empat. Jakarta (2006).

[34]Hartatik, I. P.: Buku praktis pengembangan SDM. $1^{\text {st }}$ edition. Laksana. Jogjakarta (2014).

[35]Winanti, M. B.: Pengaruh Budaya Organisasi dan Motivasi Terhadap Kinerja Karyawan pada PT Atri Distribution. Jurnal Ilmiah Program study Sastra Inggris, Vol. 1, 16 (2013).

[36]Organ, D. W.: Organizational citizenship behavior: It's construct clean-up time. Human Performance. Vol 10, pp. 85-98 (1977).

[37]Bolino M. C., Turnley, W. H. Bloodgood J. M.: Citizenship Behavior and the Creation of Social Capital in Organizations. The Academy of Management Review. Vol 27(4), pp. 505-522 (2002).

[38]Agustiningsih H. N., Thoyib A, Djumilah H. \& Noermijati N.: The Effect of Remuneration, Job Satisfaction and OCB on the Employee Performance. Science Journal of Business and Management. Vol 4 (6), pp. $212-222$ (2016).

[39]Podsakoff, N. P., Whiting, S. W., Podsakoff, P. M., \& Blume, B. D.: Individual and organizational level consequences of organizational citizenship behaviors: A meta-analysis. Journal of Applied Psychology, Vol. 94 (1), 122 (2009).

[40]Mangkunegara, A. P.: Evaluasi kinerja SDM. $2^{\text {nd }}$ edition. PT Refika Aditama. Bandung (2006).

[41]Byars, L. L \& Rue, L. W.: Human Resoucer Management, $6^{\text {th }}$ ed. The Mc Graw-Hill. North America (2000).

[42]Sedarmayanti.: Manajemen sumber daya manusia, reformasi birokrasi, dan manajemen negeri sipil. PT Refika Aditama. Bandung (2014).

[43]Bevan, S.: Good Work, High Performance and Productivity. The paper prepared for the European HR forum, Lisbon. retrieved from http://www.theworkfoundation.com/Download Publication / Report / 316_Good\% Work\% High\% Performance\% 20and\% 20Produktivity.pdf (2012).

[44]Ismail, I.: Pengaruh Budaya Organisasi Terhadap Kepemimpinan Dan Kinerja Karyawan Pemerintah Kabupaten Kabupaten di Madura, Ekuitas, Vol 12, 1 pp. 18-36 (2008).

[45]Deikme, P.: Motivasi kerja dan budaya organisasi pengaruhnya terhadap kinerja pegawai Bagian Keuangan Sekda Kabupaten Mimika Provinsi Papua. Jurnal EMBA, Vol. 1(3), pp. 980-986 (2013).

[46]Sani, A.: Role of procedural justice, organizational commitment and job satisfaction on job performance: The mediating effects of organizational citizenship behavior.state islamic university of Maulana Malik Ibrahim Malang, (2013).

[47]Prawirosentono, S.: Kebijakan kinerja karyawan. BPFE. Yogyakarta (2008).

[48]Priyanto, D.: Mandiri belajar SPSS (Statistical Product Service Solution) untuk analisis data dan uji statistic. Mediakom, Yogyakarta (2009).

[49]Ghozali, I.: Aplikasi Analisis Multivariate dengan Program SPSS. UNDIP, Semarang (2009).

[50]Lina, Dewi.: Analisis Pengaruh Kepemimpinan dan Budaya Organisasi Terhadap Kinerja Pegawai dengan Sistem Reward Sebagai Variabel Moderating. Jurnal Riset Akuntansi dan Bisnis, Vol. 14(1) (2014).

[51]Kesuma, A.: Pengaruh lingkungan kerja, motivasi, dan budaya organisasi terhadap kepuasan kerja serta dampaknya terhadap kinerja pegawai. Jurnal Bisnis dan Mangemen, 1(4) (2007). 